\title{
Responsibility for Migration Offences under the Laws of Foreign Countries
}

\author{
Margarita Urda* \\ Southwest State University \\ 94, 50 years of October Str., Kursk, 305040, Russia
}

Received 30.01.2019, received in revised form 28.02.2019, accepted 07.03.2019

\begin{abstract}
Legislations offoreign countries on responsibility for committing offences in the field of illegal migration have been subjected to the comparative legal study. Its purpose is to identify the characteristics of criminalization and penalization of relevant offences in foreign countries and to offer proposals for improving the criminal legislation of the Russian Federation on their basis. In addition to the comparative legal method, formal legal, formal logical, dialectical and systematic methods are used in the paper. The result of the study was the creation of the author's classification of crimes in the sphere of illegal migration, which allowed the author to formulate priority areas for improving the existing mechanism of counteraction to illegal migration in the Russian Federation. Scope of regulation: lawmaking and education. Based on the study results, conclusions on the necessity to give criminal significance to the deportation of foreign citizens and stateless persons, as well as toughening the responsibility for organizing illegal migration of several persons or a person who are prohibited from entering the state, have been drawn up.
\end{abstract}

Keywords: illegal migration, counteraction, criminal liability, violations of migration legislation, criminal legislation of foreign countries.

Research area: law.

Citation: Urda, M. (2019). Responsibility for migration offences under the laws of foreign countries. J. Sib. Fed. Univ. Humanit. soc. sci., 12(3), 470-491. DOI: 10.17516/1997-1370-0405.

\section{Introduction}

The problem of illegal migration is one of the new challenges and threats of the present days. Its public danger is comparable with terrorism, drug trafficking and human trafficking, which leads to the counteractions to its manifestations, including the criminal measures. At the same time, migration is a real ongoing

(c) Siberian Federal University. All rights reserved

* Corresponding author E-mail address: urda.ru@rambler.ru

This work is licensed under a Creative Commons Attribution-NonCommercial 4.0 International License (CC BY-NC 4.0). 
process, caused by negative political, socio-economic and environmental reasons. At the international level, the complex connection of migration with the economic development of the countries of origin, transit, and host states is recognized (Azose, Raftery, 2019). These circumstances predetermine the necessity to develop a balanced criminal policy to counteract illegal migration. In this context, comparative studies of criminal responsibility for criminal offences in the considered sphere are of great importance. Peculiarities of legal thinking, social and cultural traditions of the national legal systems formation have determined the difference in approaches in the nature and scope of criminal legal means to counteract the phenomenon of illegal migration, thus determining the methodological importance of sharing experience to optimize criminal law protection of national interests under conditions of real immigration processes. Comparative studies of the institute of criminal responsibility in the field of illegal migration are not developed. The most significant work in the study of the identified problem is the work of the employees of the Institute of Legislation and Comparative Law under the Government of the Russian Federation (Artemov, Vlasov, Golovanov, 2012). Some aspects of the topic were featured in works devoted to the study of the illegal migration organization - the most dangerous criminal offence in the area under consideration (Baburina, 2010; Akhmedov, 2015; Andryushenkov, 2016). However, the works of these authors did not reveal the approaches to the criminalization of the considered actions and did not take into account present changes in criminal legislation, both in Russia and in other countries, as well as the systemic nature of the mechanism of criminal law counteraction to illegal migration.

\section{Theoretical framework}

Despite a high level of theorization, comparative law is one of the most soughtafter sciences of great practical importance. Comparison of various legal institutions of foreign legislation allows for a deeper understanding of the nature of the phenomena that are taking place, especially new ones, the regulation and protection of which are just being formed. In addition to gnoseological, comparative law has practical goals: it contributes to the legislation unification of various states, which is especially important in the context of the modern migration policy formation, taking into account the complex and controversial nature of migration determined by the integrative processes taking place in the world. Moreover, foreign lawmaking experience serves as the basis for generating proposals for improving national legislation. 


\section{Statement of the problem}

Issues of understanding, legal regulation and counteraction to the negative manifestations of migration processes are placed high in modern humanitarian studies, both in Russia and other countries. Various aspects of this issues are of interest to economists (Djajić, Vinogradova, 2019), sociologists (Kim, 2019; Beck, et al., 2019; Nakache, 2018), political scientists (RodríguezIzquierdo, Darmody, 2017; Hoesch, 2017), and lawyers (Flores, Schachter, 2018; Markovska, Serdyuk, Sokurenko, 2019; Helbling, Leblang, 2019; Scheel, 2018; Bilger, 2018).

This paper attempts to identify not only the scientific and theoretical, but also the practical potential of the results of the comparative study on criminal offences in the sphere of illegal migration.

Before turning to the analysis of the features of the legislation of foreign countries that establish criminal liability for the offenses in the field of illegal migration, a preliminary clarification regarding the comparative study subject will be made. Within the framework of this study, the norms of criminal legislation of the countries of the post-Soviet space, as well as different states of the Romano-Germanic and Anglo-Saxon legal families, such as Great Britain, the USA, Canada, Australia, Germany and France are subjected to comparative legal research. The choice of some states as the object of study is determined by the common legal traditions based on the common historical past, and other states by the greatest socio-economic attractiveness for migrants and (or) due to their migration policy, the specificity of their legal systems, as well as newness and the peculiarity of the individual compositions.

At the same time, it should be noted that the norms for counteraction to illegal migration in the criminal legislation of these states are not always and not fully comparable. The author of the present paper sees the task not in the study of all the properties without exception, which is impossible, given the specific framework of the study, but in identifying the main approaches to the criminalization of the aforementioned offences and in their classification. The use of such a technical and legal method as classification, helps to identify common features and functional orientation of penal prohibitions in the field of illegal migration and, as a result, contributes to the deeper understanding of the phenomenon under study. This, in turn, is a prerequisite for improving the existing mechanism for counteracting the negative manifestations of illegal migration. 


\section{Methods}

In addition to the comparative legal method, the formal legal method, the formal logical method, the dialectical method, systematic research method, etc. are used in this work.

\section{The main approaches to criminalization and classification of criminal offenses in the field of illegal migration}

It is possible to conditionally identify three main approaches to criminalizing criminal offenses in the field of illegal migration depending on the volume and presence in the criminal legislation of foreign countries.

The first approach is traditional. It is characterized by the absence of criminal law prohibitions of illegal migration. In order to combat the manifestations of this negative phenomenon, traditional compositions, that have a functional significance from the outset rather than the actual fight against illegal migration can be used. The peculiarity of such norms is the absence of characteristics directly indicating violations of migration legislation.

A number of neighboring countries, in particular: the Republic of Turkmenistan, the Republic of Azerbaijan, the Republic of Armenia and the Republic of Kyrgyzstan, the criminal legislation of which does not contain specific tools to combat illegal migration, use this approach.

Counteraction to the offenses in this area is implemented using such traditional elements as the illegal crossing of the State Border, as well as separate types of informational and official crimes facilitating its commission.

The second approach is defined by the author as a systematic one, which implies the existence of a system of criminal law prohibitions against illegal migration, accumulated in one normative act - the Criminal Law. In addition to the above traditional compositions, such approach is characterized by the presence of a specific norm or norms directly aimed at combating illegal migration. These elements are distinguished by the complexity of formulation and novelty. A peculiarity of their construction is that they are of blanket nature and contain signs of migration legislation violations.

This approach is reflected in the legislations of the majority of neighboring countries: the Criminal Code of the Republic of Kazakhstan, the Criminal Code of the Republic of Belarus, the Criminal Code of the Republic of Moldova, the Criminal Code of the Republic of Latvia, the Criminal Code of the Republic of Lithuania, the Criminal Code of the Republic of Estonia, the Criminal Code of Georgia, the Criminal 
Code of Ukraine, the Criminal Code of the Republic of Uzbekistan, and the Criminal Code of the Republic of Tajikistan.

In contrast to the traditions of the Russian legislation, according to which all criminal law standards are to be included in the Criminal Code, the system of criminal legislations of the most countries of the Romano-Germanic and Anglo-Saxon legal families, in addition to the criminal law itself, includes other sectoral regulatory legal acts regulating certain relations and, among other things, establishing measures of criminal liability for violating the requirements formulated in them.

Thus, the system of criminal law measures to combat illegal migration of the countries adhering to the third differential approach includes, on the one hand, common criminal offences (forgery, official misconduct, human trafficking, etc.), which focus, as a rule, is criminal law; on the other hand, there are special tools to counteract illegal migration contained in the sectoral migration legislation.

Thus, criminal law prohibitions related to illegal migration are reflected in the numerous British immigration laws: the Immigration Acts 1971 and 1988, the Asylum and Migration Appeals Act 1993, Immigration and Asylum Act 1999, Nationality, Immigration and Asylum Act 2003, Identity Documents Act 2010, Forgery and Counterfeiting Act 1981, etc.

In addition to Criminal Laws, criminal liability measures for violating migration legislation can be found in the Australian Migration Act 1958, the Canadian Immigration and Refugee Protection Act 2002, the US Immigration and Nationality Act, the German Residence Act, in the French Code of Entry and Stay of Foreigners and the Right to Asylum, as well as in other sources.

Legislations of other countries of the Romano-Germanic and Anglo-Saxon legal families can be characterized in the same way.

The diversity of compositions and the differences in the functional meaning of criminal offences in the area under consideration makes it preferable to use not a regional geographic, but the institutional method in their study, and allows to classify them as follows:

- criminal violations of the legislation requirements regarding entry, exit, transit and residence of foreign citizens (stateless persons) in the territory of a foreign state;

- criminal violations of the legislation requirements regarding employment of migrants;

- criminal unlawful use or falsification of documents, committing other deceptive actions necessary for obtaining nationality, residence permit, etc. 
- criminal violations of the requirements for expulsion of foreign citizens (stateless persons);

- other criminal violations of migration legislation.

In this paper they will be considered in more detail.

\section{Criminal violations of the legislation requirements regarding entry, exit, transit and residence of foreign citizens (stateless persons) in the territory of a foreign state}

Depending on parties, two subgroups can be distinguished in this group of criminal offenses: 1) criminal violations of the established requirements for entry, exit and residence in the territory of a foreign state committed by foreign citizens (stateless persons); 2) criminal assistance to violation of the established requirements for entry, exit, transit and residence of foreign citizens (stateless persons) in the territory of a foreign state committed by other persons.

The first subgroup includes the traditional composition of the illegal crossing of the State border, which is known to almost all the countries of the post-Soviet space.

The definition of "illegal crossing of the State border" is used to define it in the Criminal Codes of the Republic of Kazakhstan (Article 392), Georgia (Article 344), the Republic of Belarus (Article 371), the Republic of Armenia (Article 329), Ukraine (Article 331), the Republic of Turkmenistan (Article 214), the Republic of Azerbaijan (Article 318), the Republic of Tajikistan (Article 335), the Republic of Lithuania (Article 291) and the Republic of Latvia (Article 284). In the Criminal Code of the Republic of Moldova (Article 322) it is "illegal crossing of the state border", in the Criminal Code of the Republic of Uzbekistan (Article 233) it is "illegal travel abroad or illegal entry into the Republic of Uzbekistan".

The specified norms are closely connected in their meanings with the Russian legislation. The discrepancies are mostly determined by the technical methods of presenting criminal law material. There are conceptual differences in the formulation of explanatory notes to the norms containing the grounds for excluding criminal responsibility, namely: violation of the rules for crossing the State border by foreign citizens and stateless persons to use the right of political asylum, unless their actions contain other elements of crime (the Criminal Code of the Republic of Belarus, the Criminal Code of the Republic of Armenia, the Criminal Code of Ukraine, the Criminal Code of the Republic of Moldova, the Criminal Code of the Republic of Turkmenistan, the Criminal Code of the Republic of Azerbaijan, the 
Criminal Code of the Republic of Tajikistan, the Criminal Code of the Republic of Uzbekistan).

The Republic of Kazakhstan, Lithuania and Latvia abandoned the elaboration of the norm on the illegal crossing of the State border using this rule, which is fully justified.

In doctrinal sources the attention to the inexpediency of its preservation was repeatedly paid. The problems of proving the absence of the above conditions and the causes of illegal crossing of the State border are among the main reasons (Sherbakov, 2009), as well as the absence of a sign of a wrongful act due to the provisions of the regulatory legislation (Rarog, Voitovich, 2008).

The Lithuanian legislator formulated the conditions for the non-application of the norm under consideration in a fundamentally different way. According to the note to Article 291 of the Criminal Code of Lithuania, it is determined that "a citizen of a foreign state who committed an act ... with the aim to illegally move from the territory of the Republic of Lithuania to a third state, is exempt from criminal responsibility ... if he/she is sent to the state from the territory of which the state border of the Republic of Lithuania was illegally crossed, or to the state of his/her nationality."

Thus, the expulsion of a foreign citizen (stateless person) is used as the basis for exemption from liability.

As a rule, the expulsion procedure is carried out in the form of an independent controlled departure, a forced transfer of a foreigner across the border or in the form of readmission, which implies an international agreement on the mutual obligations of the participating states to receive their citizens (and, in some cases, foreigners who formerly stayed or resided in this state), subjected to expulsion from another state back.

Some neighboring countries expand the boundaries of the criminalization of illegal migration and, in addition to the prohibition of illegal crossing of the State Border, establish criminal liability for violation of the rules of stay in the receiving state by foreigners (stateless persons).

In accordance with Article $371^{2}$ of the Criminal Code of Belarus staying of these persons without the necessary documents (visa, migration card, passport, etc.) or the use of invalid documents; non-observance of the established procedure for registration or movement and the choice of a place of residence; evasion of departure after a certain period of stay; transit rules violation; violation of the rules of labor, business or other activities are recognized as such. The condition of the punishment for this crime is a sign of administrative prejudice - double administrative liability for the same actions. 
The same prohibition (with the exception of non-observance of the procedure for undertaking labor, business or other activity) can be found in Part 1 of Article 224 of the Criminal Code of Uzbekistan.

The basis of the second type of crimes under consideration is a rule on the organization of illegal migration and offenses comparable to it.

The norm with the same name can be found in the criminal legislation of Kazakhstan (Article 329), Belarus (Article 371'), Moldova (Article 362') and Tajikistan (Article $352^{2}$ ). However, the approaches in its formulation are significantly different.

The criminal law prohibition formulated by the Belarusian legislator in Article $371^{1}$ of the Criminal Code of Belarus is the closest in its content to the Russian norm providing responsibility for organizing illegal migration (Article $322^{1}$ of the Criminal Code of the Russian Federation). The following alternative actions are recognized as criminal penalties in the indicated norm: organizing, directing or facilitating the activities on illegal entry into the Republic of Belarus, staying in the territory of the Republic, transit through it or leaving the Republic by foreign citizens or stateless persons.

The Criminal Code of Kazakhstan discloses the organization of illegal migration (Article 329) by indicating the ways of its commission: “... by providing vehicles, forged documents or accommodation, as well as providing other services for illegal entry, exit and movement across the territory of the Republic of Kazakhstan to citizens, foreigners and stateless persons."

Despite the indication of the norm of individual methods of committing the crime under consideration in the disposition, their open list draws attention. This is consistent with the justified position, reflected in a similar Russian norm, the ways of committing this crime may be different, therefore, there is no need to list them.

The Moldovan legislator emphasizes the mercenary motive of the organization of illegal migration (Article $3621^{1}$ of the Criminal Code), pointing out to the goal of committing this crime in the norm - to obtain, directly or indirectly, the financial or material benefits of illegal entry, stay, transit or departure from the territory of the state of a person who is not a citizen or resident of that state.

Such formulation creates certain difficulties in providing an evidence base. At the same time, it should be noted that this approach is correlated with the generally recognized international standards to combat illegal migration, enshrined in the Protocol against the Smuggling of Migrants by Land, Sea and Air, supplementing the United Nations Convention against Transnational Organized Crime. In this way, 
Article 6 of the Protocol defines the obligations to criminalize the considered acts committed for the purpose of obtaining financial or other material benefits.

The content of the organization of illegal migration in a certain degree can be correlated with Article $335^{1}$ of the Criminal Code of Tajikistan on liability for the organization of illegal entry of foreign citizens or stateless persons into the Republic, or illegal transit through the territory of the Republic, Article $344^{1}$ of the Criminal Code of Georgia, which establishes liability for the illegal transportation of migrants across the State Border of Georgia and/or the creation of appropriate conditions for their illegal stay in Georgia, Article 332 of the Criminal Code of Ukraine, which provides liability for the illegal transfer of a person across the State border of Ukraine. A similar rule can be found in the Criminal Code of Lithuania (Article 292) and the Criminal Code of Latvia (Article 285).

The legislation of the Romano-Germanic and Anglo-Saxon legal families does not use the concept of "organizing illegal migration" or "illegal crossing of the State border", meanwhile it provides for a wide range of illegal acts that can be correlated with these elements.

The first subgroup of the considered variety of elements includes the provision on liability for the illegal entry into the territory of the United Kingdom of a person who is not a citizen, established by the Immigration Act 1971.

In fact, the same prohibition can be found in $\$ 95$ of the German Residence Act, which establishes the responsibility of an alien who entered Germany without the permission required by $\S 404$ of the Third Book of German Social Code (Gesetzüber den Aufenthalt, die Erwerbstätigkeit und die Integration von Ausländernim Bundesgebiet).

The illegal entry of a foreigner under the USA law means a person's entry into the territory of the state at an inopportune time or in an un-designated place (Title 8 , Chapter 12, Subsection II, Part VIII, \$1325 of the US Code).

France also establishes criminal liability measures for foreigners who violate the requirements for the crossing of the borders of the Schengen Agreement, including those for whom the decision to prohibit entry was taken in another Schengen State (Code de l'entréeet du séjour des étrangers et du droitd'asile).

Almost all countries of the group under consideration provide for criminal liability for facilitating the illegal entry and (or) stay of foreigners in the territory of the corresponding state.

Under the US law, both smuggling of migrants (attempt of smuggling) and concealing of foreigners are criminalized (Title 8, Chapter 12, Subsection II, Part VIII, 
$\S 1324, \S 1324 \mathrm{a}$ of the US Code). UK Immigration Act 1971 criminalizes assistance in illegal migration to an EU member state; offence of knowingly and for gain facilitating the arrival in the United Kingdom of an asylum-seeker, as well as offence of doing an act which facilitates a breach of a deportation order in force against an individual and violation of administrative rules on entry (Articles 24, 25, 25a). German migration legislation criminalizes incitement or promised facilitation in the entry of a foreign citizen into the territory of Germany, as well as his/her stay in the territory without the necessary documents. At the same time, the following criminality is provided as alternative conditions for committing these acts: the purpose of obtaining material gain, re-offending or committing the act concerning several foreigners (Section 96 Gesetzüber den Aufenthalt, die Erwerbstätigkeit und die Integration von Ausländernim Bundesgebiet).

Criminal penalties for the smuggling of migrants are provided for in chapter $12 \mathrm{~A}$ of the Australian Migration Act. They are distinguished by quite tough sanctions. A sanction of up to 10 years in prison is established for organizing the arrival and facilitating the arrival in Australia of a person who is not a citizen of this state and does not have a legal right to be in it. The same measure of liability is provided for material support to the smuggling of migrants, whether or not the smuggling took place, as well as harboring an illegal citizen or a person subjected to expulsion or deportation (Australian Migration Act, Section 233a, 233d, 233e).

Canadian legislation is characterized by a wide variety of means for counteraction to illegal migration and human trafficking. In particular, Article 118 of the Immigration and Refugee Protection Act 2002 establishes responsibility for organizing the entry into the territory of the state of persons by abduction, deception, fraud, misleading, or the threat of violence. At the same time, the notion "organization of entry" is interpreted rather broadly and includes hiring of workforce, their transportation, reception and concealment after entering the territory of Canada. The liability is imprisonment up to life sentence and a fine. According to the aforementioned law, organization, stimulation, inducement, help or assistance in entering the territory of a specified state to one or several persons who do not have relevant travel documents, as well as counseling in order to facilitate illegal entry into Canada (Article 117 of the Legislation) get independent validity. The norm of responsibility for disembarking a person (group of persons) at sea for the purpose of inducing, abetting or aiding in illegal entry into the territory of Canada (Article 119 of the Law) is distinguished by its peculiarity. 
France, in its domestic legislation, provided measures to counteract illegal migration not only to ensure its own security, but also in the interests of the entire European Community, as well as the countries that ratified the Protocol against the Smuggling of Migrants by Land, Sea and Air. With this purpose they established responsibility for any person who directly or indirectly facilitated or attempted to facilitate the illegal entry, movement or stay of a foreigner in France, or in the territory of another Member State of the Schengen Convention of 1990, or in the Member State of the Protocol against the Smuggling of Migrants by Land, Sea and Air, supplementing the United Nations Convention against Transnational Organized Crime of 2000 (Code de l'entréeet du séjour des étrangers et du droitd'asile).

\section{Criminal violations of the legislation requirements regarding employment of migrants}

Legislators of some foreign countries give independent significance to violations related to the illegal employment of migrants in the system of criminal offences in the sphere of illegal migration.

In order to counteract illegal labor migration, the Kyrgyz and Kazakh legislators have taken the path of criminalizing violations of the rules for attracting and using foreign labor. The responsibility for this crime is held in Article 395 of the Criminal Code of Kazakhstan. The condition for the punishability for this crime is repeated employment of migrants without permits, as well as violation of the rules for the use of foreign labor.

A non-standard approach to establishing responsibility for the offences under consideration can be found the Tajik legislation. The Criminal Code of Tajikistan understands organization of illegal migration as organization of smuggling and employment of the citizens of the Republic of Tajikistan abroad (Part 1 of Article 3352) and the employment of migrants by a person who does not have the appropriate license to carry out this type of activity (Part 2 of the same Article).

Under the UK law, the institution under consideration includes hiring an employee breaching immigration law regulations (Article 8 of the Asylum and Immigration Act 1996). The similar element is provided for by Australian legislation (Article 245 AA, $245 \mathrm{AB}$, Article $245 \mathrm{AC}$ of the Migration Law). French labor legislation also establishes criminal liability measures for persons who use the labor of illegal migrants directly or through intermediaries (Article L. 8256-1 Code du travail).

The Law on Counteracting Illegal Labor Activity and Illegal Employment (SchwarzArbG) criminalizes the substantial disproportion between the working 
conditions of foreigners and the working conditions of German workers who perform similar or comparable activities. If a crime is committed professionally or motivated by personal greed, it is punished by imprisonment (§10). Illegal employment of five or more foreigners at the same time is considered as an aggravating circumstance and entails a more severe punishment (\$11).

In the American legislation, the responsibility for committing the crime under consideration is also correlated with the number of illegal migrants employed and, moreover, with the number of offenses committed, and is differentiated by various penalties. At the same time, depending on the circumstances of the case, the employer may be sentenced to imprisonment by the court decision (Title 8, Chapter 12, Subsection II, Part VIII, §1324a of the US Code).

In Canada, it is also criminalized to commit an offense by negligence. The law establishes the employer's responsibility for hiring a foreigner who does not have a work permit if, when hiring such a person, the employer did not check the person's documents with due diligence (Article 124 of the Immigration and Refugee Protection Act 2002).

A rather wide spectrum of criminal offences of the group under consideration in the far abroad is predetermined by the implementation of international and European standards to counteract illegal labor migration in the international law, in particular: the 1990 International Convention on the Protection of the Rights of All Migrant Workers and Members of their Families, ILO (No. 143) Convention on Abuse of Migration and on Ensuring Equal Opportunities and Treatment of Migrant Workers 1975, Directive 2009/52/EU of the European Parliament and the Council of the European Union of June 18, 2009 on the establishment of minimum standards for sanctions and measures for the employers of illegally staying third-country nationals, as well as some others. Russia is not a party to these international acts.

\section{Criminal unlawful use or falsification of documents, committing other deceptive actions necessary for obtaining nationality, residence permit, etc.}

This kind of criminal offences has not received wide distribution in the legislation of the countries of the neighboring countries. Only the Estonian Criminal Law gives independent significance to informational crimes in the field of migration. So, in Article 186 of the Criminal Code of the Republic of Estonia, along with forgery and the use of false official documents, it is criminalized to commit such illegal acts in relation 
to a document certifying permanent residence. Independent criminal law significance within the framework of the offense provided by Article 187 of the Criminal Code of the Republic of Estonia is attached to the reporting of false information or hiding information when applying for Estonian citizenship, issuing a document certifying the identity and citizenship of an Estonian citizen, residence permit or passport of an alien.

In far abroad, by contrast, the criminalization of the considered variety of offences is a common phenomenon.

In this way, along with the general elements that violate the procedure of official document circulation formulated in the UK Identity Documents Act 2010, the legislation of the country provides special responsibility for the forgery and use of immigration (registration) documents.

Crimes aimed at forgery and illegal use of documents required for obtaining citizenship, naturalization, residence permit, etc. are reflected in the US criminal law ( $\$ 1422$ of the US Criminal Code) and in the US immigration legislation (Title 8, Chapter 12, Subsection II, Part VIII, §1425 of the US Code). It is referred to the documents used to confirm the identity, registration of a foreigner, work permits, passports, visas, or other documents that can be used for the purposes of illegal entry, legalization of stay in the state, receiving immigration benefits, etc.

Canadian law criminalizes the use of a fraudulently acquired certificate of naturalization or citizenship (Article 57 of the Criminal Code of Canada), the transfer of naturalization certificate (Article 58 of the Criminal Code of Canada). The group of offences under consideration includes elements of crime provided by the Immigration and Refugee Protection Act 2002, establishing responsibility for advising on the provision of inaccurate information that may entail the issuance of documents to an immigrant (Articles 126-129).

Australian legislation contains a wide range of illegal criminal offences in the sphere of migration, which are reflected in the Australian Migration Act, as well as in the Australian Criminal Code.

In particular, according to the Migration Law, the following acts are recognized as criminally liable: the use of a visa issued to another person by a foreign citizen (Article 236); the provision of false information to the immigration service (Article 245); the provision of immigration service with false documents or knowingly fraudulent information about oneself or other persons (Article 234 (1); illegal transfer of documents to another person for their subsequent use (Article 234 (2)), etc. According to the Australian Criminal Code, it also includes production or submission of a forged 
document certifying the identity or a travel document or an original document, belonging to another person in order to use it for illegal entry into a foreign country, committed out of mercenary motives (Article $73.8-73.10$ ), as well as possession or destruction of these documents in order to conceal the citizenship of a person and facilitating his/her illegal entry into a foreign country (Article 73.11).

Under German legislation, along with falsification of documents, which includes the chapter of the Criminal Code (Strafgesetzbuch), the Residence Act establishes independent responsibility for not providing, or incomplete or unreliable provision of personal data in order to establish the identity of a person (Gesetzüber den Aufenthalt, die Erwerbstätigkeit und die Integration von Ausländernim Bundesgebiet).

\section{Criminal violations of the requirements for expulsion of foreign citizens (stateless persons)}

Some neighboring and far abroad countries establish criminal liability of an alien (stateless person) for non-compliance with the decision on expulsion from the receiving state.

Such elements are reflected in the Criminal Code of the Republic of Kazakhstan (Article 393) and the Criminal Code of the Republic of Belarus (Article 371'1). A similar norm can be found in the US legislation. It establishes responsibility for the refusal to leave the territory of the state within 90 days from the moment of the adoption of the relevant decision by the migration authorities or the court. In addition, the US legislator provided liability for the actions to prevent or impede the departure of an alien who is denied residence in the state (Title 8, Chapter 12, Subsection II, Part VIII, $\$ 1253$ of the US Code). Herewith, the law provides the possibility of exemption from liability in case of taking legal actions aimed at canceling the decision on entry ban or expulsion: in addition, a delay in the execution of such a decision may be granted due to age, health and other circumstances. At the same time, the US law establishes special measures that increase the responsibility of an alien who does not execute the expulsion decision, if the deportation was the result of a conviction for having committed three or more drug-related crimes, offences against person or serious offences, was the result of cooperation with a terrorist organization or the result of recognition of a person who does not have the right to enter the United States (Title 8, Chapter 12, Subsection II, Part VIII, $\$ 1326$ of the US Code). Those individuals who facilitate the stay of such foreigners in the United States also face enhanced responsibility (Title 8, Chapter 12, subsection II, part VIII, §1327 of the US Code). 
Criminal liability for non-execution of the decision on expulsion is provided for by the German legislation. In accordance with part 2 of $\S 95$ of the Residence Act, a person who: a) being expelled from the territory of Germany, illegally enters Germany or stays for temporary residence, or b) provides the competent authority with false or incomplete documents or personal data with the aim of misleading them for these purposes, is punishable by imprisonment or fine (Gesetzüber den Aufenthalt, die Erwerbstätigkeit und die Integration von AusländernimBundesgebiet).

A different approach to solving the issue of the presence of "undesirable" aliens in the territory of the state is revealed by the French legislator, establishing the prohibition of staying in the French territory not as an independent corpus delicti, but as a criminal sanction that is applied to any alien who is guilty of committing a crime or an offence (L.131-30 of the Criminal Code of France).

Expulsion of a foreigner or a stateless person as an additional type of punishment is also used by the criminal law of some neighboring countries, in particular: the Criminal Code of the Republic of Latvia (Article 43), the Criminal Code of the Republic of Kazakhstan (Article 51), the Criminal Code of the Republic of Azerbaijan (Article 52).

\section{Other criminal violations of migration legislation}

Other violations of immigration legislation that provide for criminal liability in the field of illegal migration include the following elements unknown to the Russian legislator: setting up of a commercial enterprise in order to evade any provisions of the migration legislation (Title 8, Chapter 12, Subsection II, Part VIII, §1325 of the US Code); smuggling of any migrant into the United States for the purposes of prostitution or other immoral purposes (Title 8, Chapter 12, Subsection II, Part VIII, §1328 of the US Code); improper disclosure of information regarding immigration, asylum or citizenship by an official (Article 18 of the UK Borders, Citizenship and Immigration Act 2009), unauthorized provision of immigration services, as well as advertising of such services (Article 91, Article 92B of the UK Immigration and Asylum Act 1999), escape from an immigration detention center, manufacture, possession, use or distribution of weapons at a detention center (Article 197A, Article 197B of Australian Migration Act), etc.

\section{Conclusion}

Completing the comparative legal analysis of criminal legal means of counteracting illegal migration, based on the legislation of foreign countries, several conclusions should be made. 
1. Most foreign countries in their legislation tend to expand their means of counteracting illegal migration by criminalizing various violations of migration legislation, which is predetermined by the reaction of the legislator to the relatively new phenomenon of illegal migration.

In the conditions of integration and globalization, such an approach seems to be fully justified and consistent with the urgent needs of the modern society. Uncontrolled migration is not only a danger to the national security of a state, it can also precipitate a crisis inside an integration association, with individual states as its members, what is now observed exemplified by the European migration crisis.

2. Lack of direct counteraction to illegal migration in the legislation of some neighboring countries seems to be explained by the fact that due to the low migration attractiveness, the problem of migration in these countries is currently not so acute that its solution could and should be guaranteed by the system of criminal law means to counter illegal migration.

3. Most foreign countries have the results of implementing the provisions of international and European standards for counteracting illegal (including labor) migration in their legislation: the Protocol against the Smuggling of Migrants by Land, Sea and Air supplementing the United Nations Convention against Transnational Organized Crime 2000, the International Convention on the Protection of the Rights of All Migrant Workers and Members of Their Families 1990, the ILO Convention No. 143 on Migrations in Abusive Conditions and the Promotion of Equality of Opportunity and Treatment of Migrant Workers 1975, the Directive 2009/52/EC of 18 June 2009 providing for minimum standards on sanctions and measures against employers of illegally staying third country nationals.

This is reflected in establishing criminal liability for the smuggling (facilitating smuggling) of migrants (Georgia, Ukraine, Lithuania, Latvia, United Kingdom, Germany, Australia, Canada, France, the USA), committing actions aimed at illegal stay of these persons in the territory of the respective state (Georgia, Uzbekistan, France, Germany, Great Britain, Canada, the USA), and violation of requirements for the employment of migrants (Kazakhstan, Tajikistan, France, Germany, Great Britain, Canada, the USA, Australia).

The same offenses should be considered as a particular case of a bigger offence the organization of illegal migration, that is reflected in the legislation of a number of neighboring countries: Belarus, Kazakhstan, Moldova, Tajikistan.

4. In addition to organizing illegal migration (illegal smuggling, stay of migrants in the territory of the respective state and carrying out other related actions), the legislation of foreign countries reveals other specific elements for counteracting illegal migration. 
These include crimes related to the illegal use and forgery of documents, as well as other deceptive actions necessary for obtaining citizenship, residence permit, etc. (Estonia, the USA, Germany, France, Australia, Great Britain, Canada, China); crimes related to the violation of the requirements for expulsion (deportation) (Kazakhstan, Belarus, the USA, Germany); violations of the rules of stay in the territory of the relevant state by migrants (Belarus, Uzbekistan) and a number of other specific offences unknown to the Russian criminal law.

The discrepancy in the volume of legal norms, as well as in the range of possible techniques and methods in their formulation, is even more significant compared to the criminal offences associated with illegal entry, exit and stay in the territory of the corresponding state.

This is explained not only by the difference in legal traditions, but, partially, by the difference in conceptual approaches to their legal assessment. In some countries, many of these acts are considered only from the point of view of administrative offenses. In the Russian Federation, for instance, the violation of the expulsion requirements, the violation of the rules for staying in the state by migrants, and the violation of the rules for employing migrants by employers lead to the administrative responsibility. In other countries if these actions are repeated, they are given a new status - a crime with the signs of punishability: administrative prejudice or repeated actions, as is the case in the Criminal Code of Uzbekistan, the Criminal Code of Kazakhstan, the Criminal Code of Belarus and in the US legislation.

5. There are following promising areas for improving criminal measures to counteract illegal migration:

- specification of expulsion of foreign citizens and stateless persons as a type of criminal punishment, just as it is reflected in the legislation of France, Azerbaijan, Kazakhstan and Latvia and as a special basis for exemption from criminal responsibility, as in Lithuania and Moldova;

- toughening the responsibility for organizing illegal migration in relation to several persons, as in the USA and Germany, and in relation to a person who is denied entry into the territory of the state, as in the USA and Great Britain.

\section{References}

Azose, J.J., Raftery, A.E. (2019). Estimation of Emigration, Return Migration, and Transit Migration Between All Pairs of Countries. In Proceedings of the National Academy of Sciences of the United States of America, 116 (1), 116-122. 
Andryushenkov, V.A. (2016). Ugolovnaia otvetstvennost' za organizatsiiu nezakonnoi migratsii [Criminal Liability for Organizing Illegal Migration]. Omsk, 209 p.

Artemov, V.Y., Vlasov, I.S., Golovanov, N.A. (2012). Migratsiia i prestupnost': sravnitel'no-pravovoi analiz [Migration and Crime: Comparative Legal Analysis], Moscow, Kontrakt, 496 p.

Asylum and Immigration Act 1996. APA Style (2018). Available at: http://www. legislation.gov.uk/ukpga/1996/49/enacted?timeline=true $\&$ view $=$ plain $\quad$ [Accessed 9 February 2018].

Akhmedov, M.N. (2015). Protivodeistvie nelegal'noi migratsii: ugolovno-pravovoi $i$ kriminologicheskii aspekty [Counteraction to Illegal Migration: Criminal Law and Criminological Aspects]. Moscow, 281 p.

Baburina, E.R. (2010). Organizatsiia nezakonnoi migratsii: ugolovno-pravovye $i$ kriminologicheskie aspekty [Organization of Illegal Migration: Criminal and Criminological Aspects]. Chelyabinsk, 208 p.

Beck, T.L., Le, T.-K., Henry-Okafor, Q., Shah, M.K. (2019). Medical Care for Undocumented Immigrants: National and International Issues. In Physician Assistant Clinics, 4 (1), 33-45.

Bilger, V. (2018). Modeling Migrant Smuggling: Testing Descriptive Types Against Recent Findings. In New Perspectives on Turkey, 59, 33-61.

Convention No. 143 on Migrations in Abusive Conditions and on the Provision of Equality of Opportunity and Treatment for Migrant Workers. APA Style. (2018). Available at: https://www.ohchr.org/en/professionalinterest/pages/cmw.aspx [Accessed 9 February 2018].

Council of Europe Convention on Action against Trafficking in Human Beings. Warsaw (2005). APA Style (2018). Available at: https://rm.coe.int/168008371d (accessed 1 February 2018)

Criminal Code Act 1995, Act No.12 of 1995 as amended. APA Style (2018). Available at: http://www.wipo.int/wipolex/ru/text.jsp?file_id=184783 [Accessed 9 February 2018].

Criminal Code of Germany [Strafgesetzbuch]. APA Style. (2018). Available at: http:// www.gesetze-im-internet.de/englisch_stgb/englisch_stgb.html [Accessed 9 February 2018].

Djajić, S., Vinogradova, A. (2019). Immigration Policies and the Choice between Documented and Undocumented Migration. In Economica, 86(341), 201-228.

European Union, Directive 2009/52/EC of the European Parliament and of the Council of 18 June 2009 providing for minimum standards on sanctions and measures 
against employers of illegally staying third-country nationals, 18 June 2009, 2009/52/ EC. APA Style (2018). Available at: http://www.refworld.org/docid/4a55ea4e2.html [accessed 9 February 2018]

Flores, R.D., Schachter, A. (2018). Who Are the "Illegals"? The Social Construction of Illegality in the United States. In American Sociological Review, 83(5), 839-868.

French Code of Entry and Stay of Aliens and Right of Asylum [Code de l'entréeet du séjour des étrangers et du droitd'asile]. APA Style (2018). Available at:https://www. legifrance.gouv.fr/affichCode.do?cidTexte=LEGITEXT000006070158 [Accessed 9 February 2018].

Helbling, M., Leblang, D. (2019). Controlling Immigration? How Regulations Affect Migration Flows. In European Journal of Political Research, 58 (1), 248-269.

Hoesch, M. (2017). Borders Policies and Refugee Protection: From Descriptive Analysis to Normative Evaluation [Grenzpolitiken und Flüchtlingsschutz: Von der deskriptiven Analyse zur normativen Bewertung]. In Zeitschrift fur Rechtssoziologie, 37(2), 313-336.

Immigration Act of Great Britain (1971). APA Style. (2018). Available at: http:// www.legislation.gov.uk/ukpga/1971/77/contents [Accessed 9 February 2018].

Immigration and Asylum Act 1999. APA Style. (2018). Available at: http://www. legislation.gov.uk/ukpga/1999/33/contents [Accessed 9 February 2018].

Immigration and Refugee Protection Act (S.C. 2001, c. 27). APA Style (2018). Available at: http:/laws-lois.justice.gc.ca/eng/acts/I-2.5/FullText.html [accessed 9 February 2018].

International Convention on the Protection of the Rights of Migrant Workers and Members of Their Families. APA Style (2018). Available at: http://www.ohchr.org/EN/ ProfessionalInterest/Pages/CMW.aspx [Accessed 9 Feb-ruary 2018].

Kim, J. (2019). Ethnic Capital, Migration, and Citizenship: a Bourdieusian Perspective. In Ethnic and Racial Studies, 42(3), 357-385.

Labor Code of France (Last modified: August 1, 2016) [Code du travail (Dernièremodification: 1 août 2016)]. APA Style (2018). Available at: https://www. legifrance.gouv.fr/affichCode.do;jsessionid=664A03297D92A2FBE6B3C245F919 2A54.tpdila07v_3?idSectionTA=LEGISCTA000018520542\&cidTexte=LEGITEXT00 0006072050\&dateTexte $=20160802$ [Accessed 9 February 2018].

German Act to Combat Undeclared Work and Unlawful Employment [Gesetz zur Bekämpfung der Schwarzarbeit und illegalen Beschäftigung]. APA Style (2018). Available at: http://www.gesetze-im-internet.de/schwarzarbg_2004/ [Accessed 9 February 2018]. 
Act on the Residence, Economic Activity and Integration of Foreigners in the Federal Territory [Gesetzüber den Aufenthalt, die Erwerbstätigkeit und die Integration von Ausländernim Bundesgebiet]. APA Style (2018). Available at: http://www.gesetzeim-internet.de/aufenthg_2004/ [Accessed 9 February 2018].

Markovska, A., Serdyuk, A., Sokurenko, V. (2019). Corruption, Policing and Migration: Exploring the Interaction Between Migrant Workers and Police in Russia, Ukraine and the UK. In International Migration, 57(1), 145-162.

Migration Act 1958 Act No. 62 of 1958 as amended. APA Style (2018). Available at: https://www.legislation.gov.au/Details/C2012C00331 [Accessed 9 February 2018].

Nakache, D. (2018). Migrant Workers and the Right to Family Accompaniment: A Case for Family Rights in International Law and in Canada. In International Migration, 56 (6), 221-235.

Rarog, A.I., Voitovich, A.P. (2008). K voprosu o neobkhodimosti sovershenstvovaniia sistemy primechanii v UK RF [On the Need to Improve the System of Notes in the Criminal Code of the Russian Federation]. In Traditsii kriminalisticheskikh shkol Kazanskogo universiteta i sovremennye tendentsii protivodeistviya prestupnosti [Traditions of Criminal Schools of Kazan University and Modern Trends in Countering Crime]. Kazan, 99-101.

Rodríguez-Izquierdo, R.M., Darmody, M. (2017). Policy and Practice in Language Support for Newly Arrived Migrant Children in Ireland and Spain. In British Journal of Educational Studies, 1-17. DOI. https://doi.org/10.1080/00071005.2017.1417973.

Scheel, S. (2018). Real Fake? Appropriating Mobility via Schengen Visa in the Context of Biometric Border Controls. In Journal of Ethnic and Migration Studies, 44(16), 2747-2763.

Sherbakov, A. (2009). Problemy ugolovnoi otvetstvennosti za nezakonnoe peresechenie granitsy [Problems of Criminal Responsibility for Illegal Border Crossing]. In Ugolovnoe pravo [Criminal Law], 5, 106-111.

The Criminal Code of Canada. APA Style (2018). Available at: http:www.efc.ca/ pages/law/cc/cc.html [Accessed 9 February 2018].

The Criminal Code of France. APA Style (2018). Available at: https://constitutions. $\mathrm{ru} / \mathrm{p}=5859 \&$ attempt $=1$ [Accessed 9 February 2018].

German Residence Act [Gesetzüber den Aufenthalt, die Erwerbstätigkeit und die Integration von Ausländernim Bundesgebiet]. APA Style (2018). Available at: http:// www.gesetze-im-internet.de/aufenthg_2004/ [Accessed 6 February 2018].

U.S. Code Chapter 69 - Nationality and Citizenship. APA Style (2018). Available at: https://www.law.cornell.edu/uscode/text/18/part-I/chapter-69 [Accessed 9 February 2018]. 
U.S. Code. 2011. Title 8. Chapter 12. Subchapter II. APA Style (2018). Available at: https://www.gpo.gov/fdsys/pkg/USCODE-2011-title8/html/USCODE-2011-title8chap12-subchapII-partVIII-sec1325.htm [Accessed 9 February 2018].

Ugolovnyi kodeks Armenii [The Criminal Code of Armenia]. APA Style (2018). Available at: www.parliament.am/legislation.php?sel=show\&ID=1349\&lang=rus [Accessed 1 February 2018].

Ugolovnyi kodeks Estonskoi Respubliki [The Criminal Code of the Republic of Estonia]. APA Style (2018). Available at: http://constitutions.ru/?p=446 [Accessed 1 February 2018].

Ugolovnyi kodeks Gruzii [The Criminal Code of Georgia]. APA Style (2018). Available at: http://matsne.gov.ge/ka/document/download/16426/143/ru/pdf [Accessed 1 February 2018].

Ugolovnyi kodeks Latviiskoi Respubliki [The Criminal Code of the Republic of Latvia]. APA Style (2018). Available at: http://www.law.edu.ru/norm/norm. asp?normID=1243424 [Accessed 1 February 2018].

Ugolovnyi kodeks Litovskoi Respubliki [The Criminal Code of the Republic of Lithuania]. APA Style (2018). Available at: http://law.edu.ru/norm/norm. asp?normID=1243877 [Accessed 1 February 2018].

Ugolovnyi kodeks Respubliki Azerbadzhan [The Criminal Code of Azerbaijan]. APA Style (2018). Available at: https://online.zakon.kz/Document/?doc_ id=30420353[Accessed 1 February 2018].

Ugolovnyi kodeks Respubliki Belarus' [The Criminal Code of the Republic of Belarus]. APA Style (2018). Available at: http://etalonline.by/ [Accessed 1 February 2018].

Ugolovnyi kodeks Respubliki Kazahstan [The Criminal Code of the Republic of Kazakhstan]. APA Style (2018). Available at: http://online.zakon.kz/Document/?doc id=31575252 [Accessed 1 February 2018].

Ugolovnyi kodeks Respubliki Kyrgyzstan [The Criminal Code of the Republic of Kyrgyzstan]. APA Style (2018). Available at: http://cbd.minjust.gov.kg/act/view/ruru/111527 [Accessed 1 February 2018].

Ugolovnyi kodeks Respubliki Tadzhikistan [The Criminal Code of the Republic of Tajikistan]. APA Style (2018). Available at: https://online.zakon.kz/Document/?doc_ $\mathrm{id}=30397325$ [Accessed 1 February 2018].

Ugolovnyi kodeks Respubliki Turkmenistan [The Criminal Code of the Republic Turkmenistan]. APA Style (2018). Available at: http://www.wipo.int/edocs/lexdocs/ laws/ru/tm/tm015ru.pdf [Accessed 1 February 2018]. 
Ugolovnyi kodeks Respubliki Uzbekistan [The Criminal Code of the Republic Uzbekistan]. APA Style (2018). Available at: http://lex.uz/pages/getpage.aspx?lact_ id=111457 [Accessed 1 February 2018].

Ugolovnyi kodeks Ukrainy [The Criminal Code of Ukraine]. APA Style (2018). Available at: http:// me-get.kiev.ua/kodeks/ugolovniy-kodeks/ [Accessed 1 February 2018].

Ugolovnyi zakon Respubliki Moldova [The Criminal Code of the Republic of Moldova]. APA Style (2018). Available at: http:// lex.justice.md/ru/331268/ [Accessed 1 February 2018].

UN General Assembly, Protocol against the Smuggling of Migrants by Land, Sea and Air, Supplementing the United Nations Convention against Transnational Organized Crime (2000). APA Style (2018). Available at: http://www.refworld.org/ docid/479dee062.html [Accessed 9 February 2018].

\title{
Ответственность за миграционные преступления по законодательству зарубежных стран
}

\author{
М. Урда \\ Юго-Западный государственный университет \\ Россия, 305040, Курск, ул. 50 лет Октября, 94
}

В работе сравнительно-правовому исследованию подвергнуто законодательство зарубежных стран об ответственности за совершение преступлений в сфере незаконной миграции. Его иелью служит выявление особенностей криминализации и пенализации соответствуюших деяний в зарубежных странах и формулирование на их основе предложений по совершенствованию уголовного законодательства Российской Федерации. Помимо сравнительно-правового метода в работе использовались формально-юридчческий, формально-логический, диалектический, системный методы. Результатом исследования явилось создание авторской классификации преступлений в сфере незаконной миграции, которая позволила автору сформулировать приоритетные направления совершенствования существующего механизма уголовного противодействия незаконной миграции в Российской Федерации. Область применения - законотворчество и образование. По результатам исследования сформулированы выводы о необходимости придания уголовно-правового значения выдворению иностранных граждан и лии без гражданства, а также ужесточения ответственности за организацию незаконной миграции в отношении лица или нескольких лии, которым въезд на территорию государства запрещен.

Ключевые слова: незаконная миграчия, противодействие, уголовная ответственность, нарушения миграционного законодательства, уголовное законодательство зарубежнных стран.

Научная специальность: 12.00.00 - юридические науки. 